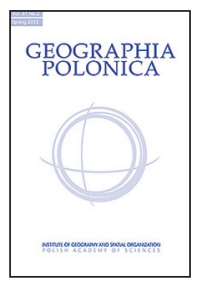 \\ INSTITUTE OF GEOGRAPHY AND SPATIAL ORGANIZATION \\ POLISH ACADEMY OF SCIENCES \\ www.igipz.pan.pl \\ www.geographiapolonica.pl
}

\title{
IDENTIFICATION OF THE ROZWAROWO MARSHES USING RADAR REMOTE SENSING
}

\author{
Tatiana Solovey \\ Polish Geological Institute - National Research Institute \\ Rakowiecka 4, 00-975 Warsaw: Poland \\ e-mail: tatiana.solovey@pgi.gov.pl
}

\begin{abstract}
The main aim of the work was to develop methods of remote identification of marshes, detection of flooded territories, and classification of plant cover on the basis of data of satellites operating in the optical and microwave spectres in particular. The research is done in 2014 on the territories of the Rozwarowo Marshes nature protected area, located in the north-eastern Poland in the delta of Oder. The backscattering coefficients $\left(\sigma^{\circ}\right)$, calculated from Radarsat-2 (Phased Array type C-band Synthetic Aperture Radar) images registered at cross polarization VH on 26 September 2014 were applied for classification of main types of wetland communities. The peculiarities of plant cover are also discovered using Normalized Difference Vegetation Index (NDVI), calculated on the basis satellite image SPOT-6 on September, the 1st, 2014. The differences in the NDVI value within homogeneous segment of plant are caused, first of all by the soil moisture. Close connection between the soil moisture and the NDVI value for the main groups of plant cover is detected. The application of coefficients $\sigma^{\circ} \mathrm{VH} / \sigma^{\circ} \mathrm{V}$, calculated on the basis of radar images at the polarization $\mathrm{VH}$ and $\mathrm{VV}$ and the big ray angle (above $40^{\circ}$ ) of incidence are suggested for identification of flooded territories.
\end{abstract}

\section{Key words}

Radarsat-2 - radar backscatter $\cdot$ wetland habitats $\cdot$ NDVI marshes monitoring

\section{Introduction}

Launching of satellites to the orbits, equipped with the SAR system has enabled new options for remote identification of marshes and evaluation of their state. Scientific direction of radar remote sensing of marshes has been researched for more than 30 years, and first of all concerned the works of the North American scientists.
The methods of radar remote sensing of marshes are argued to be effective for exploration of soil moisture and vegetation cover (Wickel et al. 2001; Kasischke et al. 2003; Pierdicca et al. 2010; Brisco et al. 2011; Budzyńska et al. 2011; Dabrowska-Zielinska et al. 2014; Ulaby et al. 2014), structure and biomass plants (Ulaby et al. 1986; Dobson et al. 1992; Le Toan et al. 1997; Moreau \& Le Toan 2003; Grings et al. 2006; Canisius \& Fernandes 
2012), flooded area (Krohn et al. 1983; Hess et al. 1990; Ramsey 1995; Townsend \& Walsh 1998; Rozenqvist et al. 2002; Martinez \& Le Toan 2007; Marti-Cardona et al. 2010; Arnesen et al. 2013).

Radar images display distribution of amplitudes of reflected from the land surface microwave signal. The value of reflected signal is determined by the factors of two categories. The first one is manifested in the technical configuration of radar: the length of generated electromagnetic wave (the most typical bands - $L, C$, and $X$ in the descending order of their length), the type of wave polarization $(\mathrm{V}, \mathrm{HH}$, $H V$, and $V H$ ), and the incident angle of generated ray. The second category is caused by the features of land surface such as roughness and moistening.

The waves of L-band are considered to be more effective means of investigation of flooding of forested lands (Hess et al. 1990, 1995; Wang et al. 1995; Bourgeau-Chavez et al. 2001; Slatton et al. 2008). Because of the longest wavelength, the waves have the best penetrating ability and reach the land surface. The $C$ and $X$ waves are reflected by the vegetation cover. Instead, the latter are better at identifying the non-forested marshes (Ramsey 1995; Pope et al. 1997; Costa et al. 1998; Budzyńska et al. 2011). A limitation of the C-band is that it can not penetrate high density forest (Li \& Chen 2005). The acute incidence angles regardless of their length are observed to have better results of remote sensing (Costa 2004; Grings et al. 2005; MartiCardona et al. 2010). The role of plant barrier grows with the increase of angle.

The value of energy of reflected radar ray depends on the height of vegetation cover and the level of wetness of land surface. High plant cover is rougher. As a result, the radar ray is reflected at different angles and most of it returns to the receiver. Such an aspect is manifested in more intense reflected signal on the radar images (Budzyńska et al. 2011; Solovey 2013). Dielectric features of soil and vegetation determined by the water content also shape the value of energy of reflected signal. Watered vegetation and moist soils reflect the radar signal more than in the dry state (Budzyńska et al. 2011; Solovey 2013).

Our overall aim was the analysis of potential of use of radar images of Radarsat-2 for the marsh identification, in particular distinguishing the flooded territories and vegetation classification. The specific objectives of our study were to analyze the radar images Radarsat-2 registered at different polarizations of radar wave were and determination optimal configuration polarizations to mapping the spatial extent of localized flooding and vegetation classification. The results of identification of flooded territories and vegetation classification with the radar images can be applied for the monitoring of the marshes moistening. It appears to be valuable for exploration of causes leading to the degradation of marsh ecosystems.

\section{Methods}

\section{Study area}

The research was done in 2014 in the marsh region of the Oder delta in the north-eastern Poland, in the Grzybnica and Wolczenica estuaries (Fig. 1). The territory refers to the Rozwarowo Marshes nature protected area included in the European network Natura 2000 in response to its uniqueness, biodiversity, and the richness of avifauna. Nature protected area of the Rozwarowo Marshes was created in 2004, its surface is 4,250 hectares.

The marshes and bogs constitute over $40 \%$ of the area (almost 1,700 hectares). The most valuable marsh ecosystems are located in the central and northern parts. They are represented by rushes (dominant Phragmites australis and Thelypteris palustris) and halophytic vegetation (Triglochin maritimum, Juncus gerardi, Plantago maritime). Forests cover $20 \%$ of the area. They are concentrated in the southern part of the region and represented by pine and floodplain forests. The western part of the Rozwarovo Marshes is transformed by agriculture with the prevalence of arable lands. In general, the agriculture lands constitute $38 \%$ of the area. 


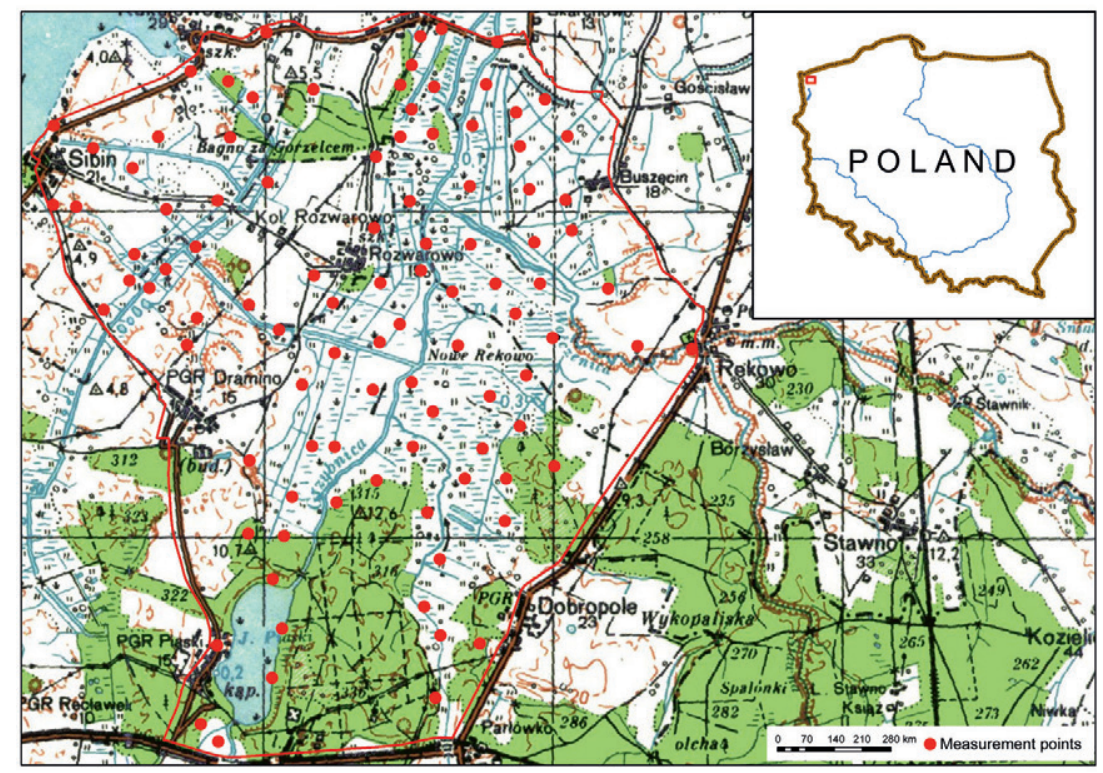

Figure 1. Site location

The surface of the territory is flat, 10 meters high above sea level, surrounded by the moraine swells, excluding the northern section adjoining to the Kamienska bay. The water level highly depends on the level of the Baltic Sea. During the storms Rozwarowo Marshes are flooded with the salty sea water. The organic deposits like lowland moss peat on the lake gyttja are distributed in the valley parts of the region. The peats of the territory are determined by the absence of forest species that imply to the variable and mostly high level of water. Maximum volume of peat reaches 6-8 meters, the average volume - 2 meters. The valleys of Grzybnica and Wolczenica are covered with the dense network of melioration channels and ditches, built in the early 20th century. At present, the melioration system has undergone reconstruction for maintaining stably high level water level.

Hydrological conditions of the territory are determined by the oceanic type of climate. The sea polar air masses, coming mostly from the north of Atlantic Ocean contain significant amount of water vapor and cause decrease of temperature in summer and warming in winter. The mean annual precipitation constitute $650 \mathrm{~mm}$ (Choiński 1998) with the dominance of precipitation of low intensity (up to $5 \mathrm{~mm}$ ). The rare heavy showers refer to the middle of vegetation period. Evaporation is 460-480 mm (Choiński 1998). The mean annual air temperature reaches $7,7^{\circ} \mathrm{C}$ with the amplitude of $20,4^{\circ} \mathrm{C}$. The warmest month is July (the average value $-17,4^{\circ} \mathrm{C}$ ); the coldest - December $\left(-0,9^{\circ} \mathrm{C}\right)$. The hydrological regime of the rivers manifests in the small amplitude of water discharge, low frequency of extreme floods, slightly low variability of annual mean water discharge, and the dominance $(70 \%)$ of underground water supply (Dynowska 1971).

\section{Satellite data}

Combining radar and optical remote sensing represents a more promising approach for wetland identification and mapping. Li and Chen (2005) evaluated the ability of Landsat TM and SAR (Radarsat-1) data to mapping wetland. For the investigation of Rozwarowo Marshes the images acquired at the optical (SPOT-6) and microwave (Radarsat-2) spectres were used. 
Satellite images of SPOT-6 were acquired in September, 2014. They were obtained in 4 specters: channel B1 - 455-525 nm (blue), channel B2 - 530-590 nm (green), channel B3 - 625-695 nm (red), channel B4 - 760-890 nm (NIR). The space resolving power constitutes 6 meters.

The images of Radarsat-2 (mode ScanSAR, Path Image SGF) are operated in the SAR

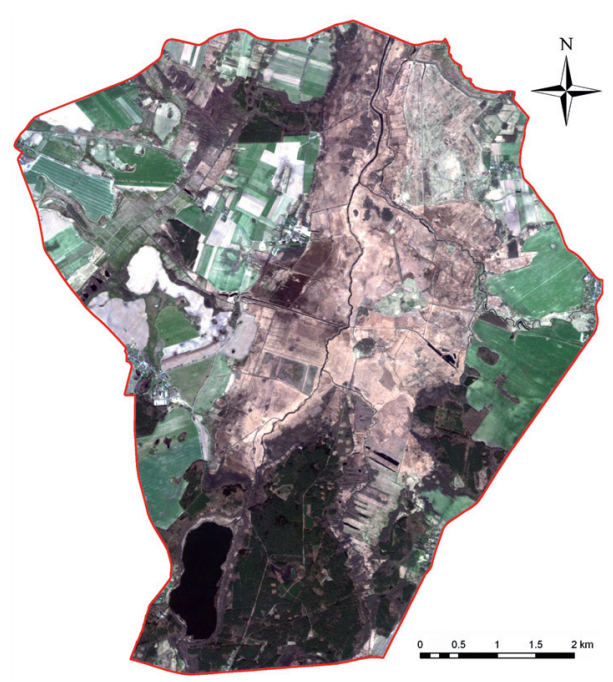

Figure 2. Red, Green, Blue (RGB) $(3,2,1) \mathrm{com}$ position of SPOT-6 image acquired on 11.09.2014

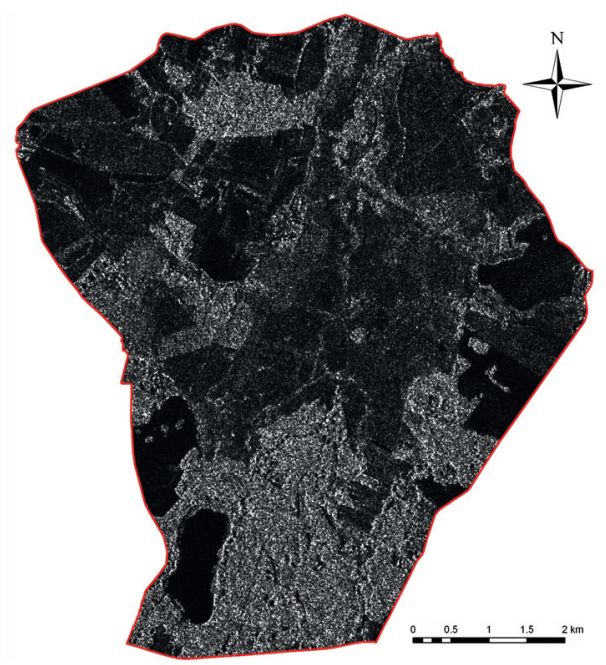

Figure 3. Radarsat- $2 \sigma^{\circ} \mathrm{VV}$ image acquired on 26.09.2014 system with the C-band and polarization $\mathrm{VH}$ and $\mathrm{V}$. The images are registered in September, 2014. The incidence angle of microwave ray is $42,96^{\circ}$ and has a spatial resolution of approximately $8 \mathrm{~m} \times 8 \mathrm{~m}$. The colour composition (Red, Green, Blue - RGB) of the SPOT-6 and Radarsat-2 (polarization WV) images is shown on the Figures 2 and 3.

Every satellite image was geometrically corrected (to the Polish CS92 - EPSG projection 2180/ETRS89). Topographic correction of microwave wave was not done because of flat type of the surface. The microwave image presented the distribution of radar brightness (i.e. elevation).

\section{In-situ data}

The field studies were undertaken during September 24-28 synchronically with the remote sensing. The studies concerned identification of the type of wetlands vegetation habitats, the inundation level, and the soil moisture. Time Domain Reflektometry(TDR) was applied for measuring of soil moisture on the depth of $15-20 \mathrm{~cm}$. The measurement accuracy was $0.01 \%$. The test sites of measurement were located in the way to cover all the diversity of the wetlands vegetation habitats. The studies were done in 100 sites. Afterwards, the GIS layer was generated on the basis of field studies of 100 sites that was used for interpretation of satellite data.

The primary satellite information was processed to find the representative indicators of identification of flooded territories and vegetation classification. Radiometric calibration of absolute data of radar images was done using the radar backscattering coefficient $\sigma^{\circ}$. The precision of the absolute radiometric calibration is approximately $\pm 3 \mathrm{~dB}$. The formula of its calculation is represented in the following way:

$$
\sigma^{\circ}=\left(\mathrm{DN}^{2} / \mathrm{K}\right) \cdot \sin (\alpha),
$$

where: $\mathrm{K}$ - absolute calibration constant, delivered for each image and polarization by Radarsat-2; DN - pixel intensity value; $\alpha$ - local incidence angle at each pixel. 
On the basis of the SPOT-6 images the Normalized Difference Vegetation Index (NDVI) was calculated. NDVI is the most widely used index for remote sensing of vegetation in the past two decades. This index has been used in many applications, including estimating crop yields and end-of-season above-ground dry biomass (Tucker 1979). NDVI is calculated on the basis of spectral reflectance from the soil-vegetation surface acquired in the visible red and near infrared spectrum of electromagnetic wave according to:

$$
N D V I=(N I R-R E D) /(N I R+R E D),
$$

where: RED - spectral reflectance in red spectrum; NIR - spectral reflectance in near-infrared spectrum.

\section{Results}

The SPOT-6 images were applied to create the land use map which is necessary for distinguishing of agricultural lands, forested territories, and water areas. The rest of the territory is represented with the marshy non-forested ecosystems. The mapping is fulfilled using the method of object classification of satellite

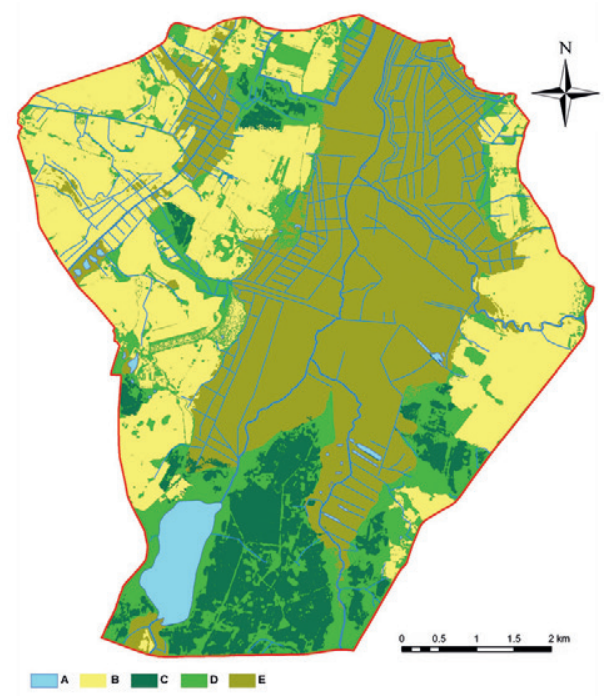

Figure 4. The land use map of the Rozwarowo Marshes region, created on the basis of the SPOT-6 satellite data. A - water body, B - arable land, C - forest, D - scrubs, E - wetlands habitats datasets. Field studies served as a basis for choosing objects required for the procedure of controlling classification. The methodic of land use mapping consists of 3 stages: 1) segmentation of satellite image with the object-based method; 2) aggregation of segments into homogeneous classes according to spectrum, topological, and morphological parameters; 3) verification of the classification results. The composition of RGB channels B3, B1 i B4 seems to be the most detailed for identification of forested and agricultural lands, and marshy ecosystems accordingly. The territories without plant cover (for example arable lands) are the most apparent at the RGB composition of the B4, B3 i B2 channels. The land use map using the object classification is presented on the Figure 4.

The backscattering coefficients $\left(\sigma^{\circ}\right)$ calculated on the basis of radar image Radarsat-2 at polarization $\mathrm{VH}$ became the basis for classification of main types of wetland communities while the cross-polarization is the most sensitive to the roughness of plant cover. The SAR-VH pixel image, presented with the backscattering coefficient, is segmented into the homogeneous objects. Using data of field estimation of 50 sites, limit values of backscattering coefficient for the main vegetation types are established. Table 1 represents limit values of backscattering coefficient for 4 main wetland communities: scrubs, reeds, sedges, and sedges-reeds. The maps of vegetation cover created on the basis of backscattering coefficients have high level of validity - 86\% (Fig. 5).

Table 1. Values of $\sigma^{\circ}$ and corresponding wetland communities

\begin{tabular}{|l|c|}
\hline$\sigma^{\circ}$ values $(\mathrm{dB})$ & Class name \\
\hline From -9 to -13 & Scrubs \\
From -13 to -16 & Sedges \\
From -16 to -17 & Reeds \\
From -17 to -19 & Sedges-Reeds \\
\hline
\end{tabular}




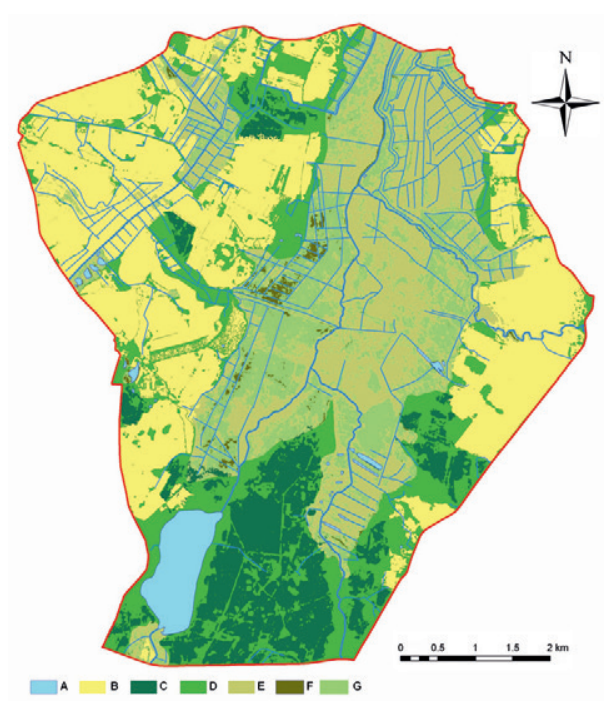

Figure 5. Map of wetland communities with the classification based on SAR VH image registered on 26.09.2014. A - water body, B - arable land, C - forest, D - scrubs, E - reeds, F - sedges-reeds, $\mathrm{G}$ - sedges

The types of wetland communities are classified according the limit values of backscattering coefficients for every class. The highest values are observed for scrubs because of the biggest roughness of surface. Minimum values are detected for sedges-reeds due to insignificant roughness of plant cover and with some parts of bare soil.
The NDVI, rather sensitive to the vegetation biomass value, is analyzed on the basis of previous map. The differences of the NDVI values within the homogeneous vegetation segment are found to be caused by the soil moisture. It manifests in the density of plant cover. The relationship between the soil moisture and NDVI value calculated for main wetland communities are shown on the Figure 6.

The benefits of radar images are that they make it possible to discover flooded regions using different compositions of microwave polarizations. While comparing images registered at vertical $\mathrm{V}$ polarization and $\mathrm{VH}$ cross-polarization, the latter is noticed to show more precisely the differences between the areas with plant cover and bare soil. Moreover, it is less sensitive to the surface roughness. In addition, vertical $\mathrm{W}$ polarization is known for deeper penetration of waves and better remote sensing of wetlands outside the forests. The Figure 7 represents colour composition (RGB) of Radarsat-2 image, where $\mathrm{VH}$ amplitude is displayed in red and $\mathrm{V}$, green and blue. Three marsh zones can be distinguished in the composition: open water, emerged bare, and bare soil.

Better efficiency of remote sensing of flooded territories is achieved with the combination of acute and right incident angles of microwave rays. The prevalence is given to colour composition (RGB), where $\mathrm{V}$ amplitude

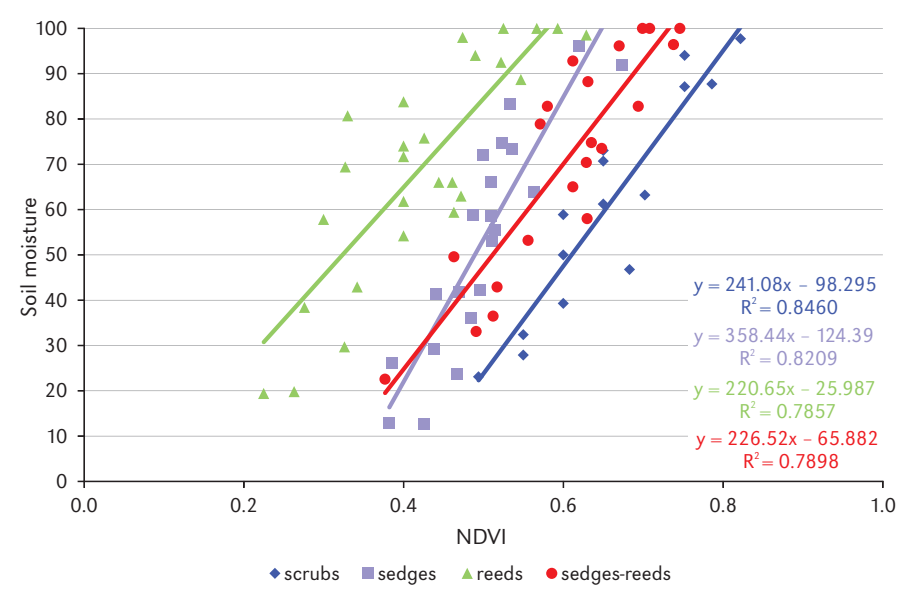

Figure 6. Relationship between soil moisture measured at the test site and NDVI calculated from SPOT-6 

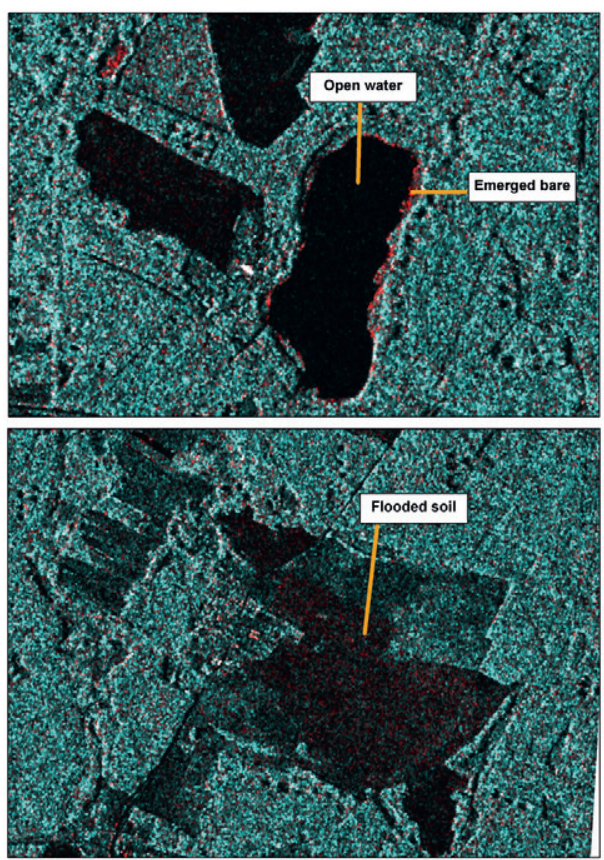

Figure 7. Rozwarowo Marshes areas extracted from the VH/V SAR amplitude scene on 26.09.2014. VH amplitude is displayed in red (polarization $\mathrm{V}$ ) and $\mathrm{V}$ green and blue

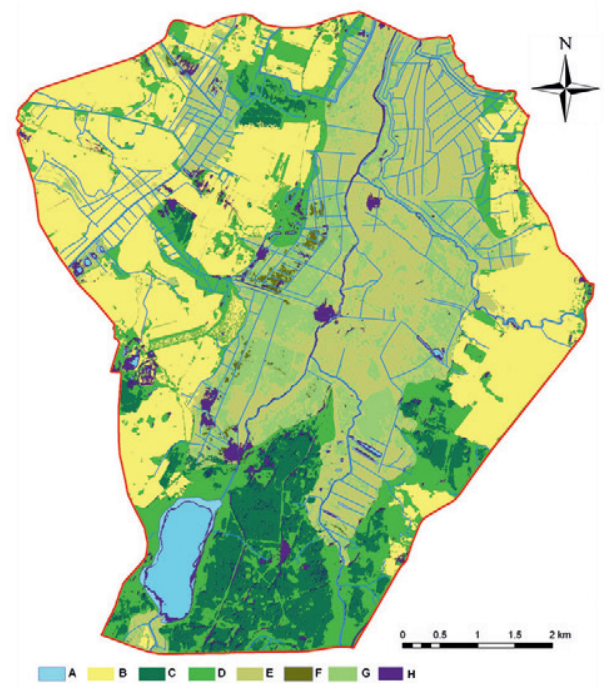

Figure 8. The map of flooded territories generated on the basis of satellite data of Radarsat-2. $\sigma^{\circ} \mathrm{VH} /$ $\sigma^{\circ} \mathrm{W}$ acquired on 26.09.2014. A - water body, B - arable land, C - forest, D - scrubs, E - reeds, F - sedges-reeds, $\mathrm{G}$ - sedges, $\mathrm{H}$ - flooded area of microwave ray with the angle $40^{\circ}$ is displayed in red; $\mathrm{HH}$ amplitude with the same angle - in green, and $\mathrm{W}$ amplitude with smaller the angle less than $20^{\circ}$ is displayed in blue (Marti-Cardona et al. 2010).

The apparent decrease of the $\sigma^{\circ}$ value in both polarizations on the flooded non-forested territories is observed on the images based on the radar backscattering coefficient $\sigma^{\circ}$, which is calculated separately for polarization $\mathrm{W}$ and $\mathrm{VH}$. In this case, more significant decrease is noticed in $\mathrm{V}$ case than $\mathrm{VH}$. Hence, flooded territories outside the forests were identified taking into account mentioned peculiarity and using relation $\sigma^{\circ} \mathrm{VH} / \sigma^{\circ} \mathrm{W}$. Flooded territories on the image created on the basis of $\sigma^{\circ} \mathrm{VH} / \sigma^{\circ} \mathrm{V}$ are noticed for rapid increase of $\sigma^{\circ} \mathrm{VH} / \sigma^{\circ} \mathrm{V}$ with the values exceeding 14. The map of flooded territories determined with the $\sigma^{\circ} \mathrm{VH} / \sigma^{\circ} \mathrm{V}$ values is shown on the Figure 8.

\section{Discussion}

The current research eliminates the problem of monitoring of moistening conditions of marshes using teledetection. The paper reveals the opportunity of data application of Radarsat-2 polarimetric SAR images to determine localization of swamp territories and distinguish the vegetation cover of non-forested marshes. The search of appropriate algorithm for the radar images interpretation is fulfilled while combining satellite data with the results of field studies on the territory of the Rozwarowo Marshes. Classification of vegetation cover involved determination of four types of wetland communities: scrubs, reeds, sedges, and sedgesreeds. The classification of swamp territories suggested detection of three marshy zones: open water, emerged bare, flooded soil. The influence of different factors on the classification of vegetation cover and the moistening conditions of marshes applying Radarsat-2 images, additional data of optical SPOT-6 satellite, and results of field measurements of the soil waters depth, soil moisture, and inundation level is explored. 
The works of Ramsey (1995), Pope et al. (1997), Costa et al. (1998), Budzyńska et al. (2011) served the basis for choosing the C-VH polarised images for classification of vegetation cover. The backscattering coefficients $\left(\sigma^{\circ}\right)$ calculated from Radarsat-2 images registered at cross polarization $\mathrm{VH}$ are the most appropriate to reveal structural differences of plan cover. Still, because of soil moisture the detection of vegetation types according to the growing state within one class is complicated. The study argued that the NDVI index, reflecting the vegetation growth state correlates closely with the soil moisture level within one class of non-forested wetland vegetation. Consequently, the NDVI application for the radar images interpretation in the context of the vegetation cover classification enables to distinguish the distribution of over-moisturised lands with the shallow soil waters.

Taking into account the research of MartiCardona et al. (2010), identification of swamps (with superficial soil waters) and flooded territories covered with vegetation becomes possible while using combined Radarsat-2 images at the $\mathrm{VH}$ and $\mathrm{V}$ polarization. Our research showed that the utilization of the $\sigma^{\circ} \mathrm{VH} / \sigma^{\circ} \mathrm{V}$ combination enables to map precisely territories with open water surface, swamps, and flooded territories with vegetation cover.

\section{Conclusions and summary}

Satellite remote sensing has several advantages for monitoring wetland resources. Its prevalence over traditional field methods manifest in the better accuracy, temporal homogeneity, and generation of spatial information in contrast to the point data of surface observations. Remote sensing enables systemic complex research of marshes on the big territory at once that is especially difficult for hard-to-reach territories. Besides, the data of satellite images represent certain parameters in the objective manner without the need for interpolation and extrapolation as in the case of in-situ data of field studies.

Suggested method of remote monitoring of marshes concerns identification of wetland communities and flooded territories and the assessment of soil moisture on the basis of satellite images operated in the microwave and optical parts of electromagnetic spectrum. The SPOT-6 images were used to create the land use map and calculation of NDVI value. Microwave datasets of Radarsat-2 and the calculation of backscattering coefficient on its basis are applied for classification of wetland communities and identification of flooded territories.

The spatial variability of plant cover can be discovered with the help of the C-band, polarization $\mathrm{VH}$, and the big incident angle of radar ray. Four types of wetland communities are distinguished. The close relationship between the soil moisture and the NDVI value is detected within the homogeneous vegetation segment.

High accuracy of identification of flooded territories using the coefficient $\sigma^{\circ} \mathrm{VH} / \sigma^{\circ} \mathrm{V}$ implies to the capability of long wave $(\mathrm{C})$ rays of SAR with the polarization $\mathrm{VH}$ and $\mathrm{V}$ and big incident angle $\left(43^{\circ}\right)$ for hydrological mapping and calibration of hydrodynamic model of marshes.

The suggested method of the swamps' identification and distinguishing the wetlands' vegetation combining radar and optical remote sensing therefore represents a more promising approach for wetland identification and mapping. The development of the study will be based on the synergistic use of radar and optical remote sensing in conjunction with GIS modeling, in particular using DEM data.

\section{Acknowledgments}

This work was supported by the Polish Ministry of the Environment under Grant "The Tasks of National Hydrogeological Agency of Poland in 2012-2014".

\section{Editors' note:}

Unless otherwise stated, the sources of tables and figures are the authors', on the basis of their own research. 


\section{References}

Arnesen A.S., Silva T.S.F., Hess L.L., Novo E.M.L.M., Rudorff C.M, Chapman B.D., MCDONALD K.C., 2013. Monitoring flood extent in the lower Amazon River floodplain using ALOS/PALSAR ScanSAR images. Remote Sensing of Environment, vol. 130, pp. 51-61.

Bourgeau-Chavez L.L., Kasischke E.S., Brunzell S.M., Mudd J.P., Smith K.B., FrICK A.L., 2001. Analysis of space-borne SAR data for wetland mapping in Virginia riparian ecosystems. International Journal of Remote Sensing, vol. 22, no. 18, pp. 3665-3687.

Brisco B., Kapfer M., Hirose T., Tedford B., Liu J., 2011. Evaluation of C-band polarization diversity and polarimetry for wetland mapping. Canadian Journal of Remote Sensing, vol. 37, no. 1, pp. 82-92.

BudzyńSKa M., DąroWSKA-ZielińSKa K., TURLeJ K., Matek I., BARTOld M., 2011. Monitoring przyrodniczy Bagien Biebrzańskich z zastosowaniem teledetekcji. Woda-Środowisko-Obszary Wiejskie, vol. 11, no. 3, pp. 39-64.

Canisius F., Fernandes R., 2012. alOS PALSAR L-band polarimetric SAR data and in situ measurements for leaf area index assessment. Remote Sensing Letters, vol. 3, no. 3, pp. 221-229.

Cholński A., 1998. Warunki obiegu wody w dorzeczu Parsęty [in:] A. Kostrzewski (ed.), Funkcjonowanie geosystemów zlewni rzecznych. Tom 1. Środowisko przyrodnicze dorzecza Parsęty - stan badań, zagospodarowanie, ochrona, Koszalin: Politechnika Koszalińska, pp. 36-51.

COSTA M.P.F., 2004. Use of SAR satellites for mapping zonation of vegetation communities in the Amazon floodplain. International Journal of Remote Sensing, vol. 25, no. 10, pp. 1817-1835.

Costa M.P.F., Moraes Novo E.M.L., Ahern E., Mitsuo II E., Mantovani J.E., Ballester M.V., PietsCh R.W., 1998. The Amazon floodplain through radar eyes: Lago Grande de Monte Alegre case study. Canadian Journal of Remote Sensing, vol. 24, no. 4, pp. 339-349.

DABROWSKA-ZIELINSKA K., BUDZYNSKA M., TOMASZEWska M., Bartold M., Gatkowska M., Malek I., Turlej K., NapiorkowsKa M., 2014. Monitoring wetlands ecosystems using ALOS PALSAR (L-Band, HV) supplemented by optical data: A case study of Biebrza Wetlands in Northeast Poland. Remote Sensing, vol. 6, no. 2, pp. 1605-1633.
Dobson M.C., Ulaby F.T., Le Toan T., Beaudoin A., Kasischke E.S., Christensen N., 1992. Dependence of radar backscatter on coniferous forest biomass. IEEE Transactions on Geoscience and Remote Sensing, vol. 30, no. 2, pp. 412-415.

DynowsKA I., 1971. Typy reżimów rzecznych w Polsce. Zeszyty Naukowe Uniwersytetu Jagiellońskiego, vol. 268, Prace Geograficzne, vol. 28.

Grings F.M., Ferrazzoli P., Jacobo-Berlles J.C., Karszenbaum H., Tiffenberg J., Pratolongo P., KanduS P., 2006. Monitoring flood conditions in marshes using EM models and Envisat ASAR observations. IEEE Transactions on Geoscience and Remote Sensing, vol. 44, no. 4, pp. 936-942.

Grings F., Ferrazzoli P., Karszenbaum $H_{\text {., }}$ Tiffenberg J., Kandus P., Guerriero L., Jacobo-BerRles J.C., 2005. Modeling temporal evolution of junco marshes radar signatures. IEEE Transactions on Geoscience and Remote Sensing, vol. 43, no. 10, pp. 2238-2245.

Hess L.L., Melack J.M., Filoso S., Wang Y., 1995. Delineation of inundated area and vegetation along the Amazon Floodplain with the SIR-C Synthetic Aperture Radar. IEEE Transactions on Geoscience and Remote Sensing, vol. 33, no. 4, pp. 896-904.

Hess L.L., Melack J.M., SimOnet D.S., 1990. Radar detection of flooding beneath the forest canopy: A review. International Journal of Remote Sensing, vol. 11, no. 7, pp. 1313-1325.

KasischKe E.S., SMith K.B., Bourgeau-Chavez L.L., Romanowicz E.A., BRUnZell S., RichardSON C.J., 2003. Effects of seasonal hydrologic patterns in south Florida wetlands on radar backscatter measured from ERS-2 SAR imagery. Remote Sensing of Environment, vol. 88, no. 4, pp. 423-441.

Krohn D.M., Milton N.M., Segal D.B., 1983. SEASAT Synthetic Aperture Radar (SAR) response to lowland vegetation types in Eastern Maryland and Virginia. Journal of Geophysical Research, vol. 88, no. C3, pp. 1937-1952.

le Toan T., Ribbes F., Wang L.-F., Floury N., Ding K.-H., Kong J.A., FuJita M., Kurosu T., 1997. Rice crop mapping and monitoring using ERS-1 data based on experiment and modeling results. IEEE Transactions on Geoscience and Remote Sensing, vol. 35, no. 1, pp. 41-56.

LI J., CHEN W., 2005. A rule-based method for mapping Canada's wetlands using optical, radar 
and DEM data. International Journal of Remote Sensing, vol. 26, no. 22, pp. 5051-5069.

Marti-Cardona B., Lopez-Martinez C., Dolz-Ripolles J., Bladè-CASTellet E., 2010. ASAR polarimetric, multi-incidence angle and multitemporal characterization of Doñana wetlands for flood extent monitoring. Remote Sensing of Environment, vol. 114, no. 11, pp. 2802-2815.

Martinez J.-M., Le Toan T., 2007. Mapping of flood dynamics and spatial distribution of vegetation in the Amazon floodplain using multitemporal SAR data. Remote Sensing of Environment, vol. 108, no. 3, pp. 209-223.

Moreau S., Le Toan T., 2003. Biomass quantification of Andean wetland forages using ERS satellite SAR data for optimizing livestock management. Remote Sensing of Environment, vol. 84, no. 4, pp. 477-492.

Pierdicca N., Pulvirenti L., Bignami C., 2010. Soil moisture estimation over vegetated terrains using multitemporal remote sensing data. Remote Sensing of Environment, vol. 114, no. 2, pp. 440-448.

Pope K.O., Rejmankova E., Paris J.F., WoodRUFF R., 1997. Detecting seasonal flooding cycles in marshes of the Yucatan Peninsula with SIR-C polarimetric radar imagery. Remote Sensing of Environment, vol. 59, no. 2, pp. 157-166.

RAMSEY III E.W., 1995. Monitoring flooding in coastal wetlands by using radar imagery and ground-based measurements. International Journal of Remote Sensing, vol. 16, no. 13, pp. 2495-2502.

Rosengvist A., Forsberg B.R., Pimentel T., Rauste Y.A., Richey J.E., 2002. The use of spaceborne radar data to model inundation patterns and trace gas emissions in the central Amazon floodplain. International Journal of Remote Sensing, vol. 23, no. 7, pp. 1303-1328.
Slatton K.C., Crawford M.M., Chang L.-D., 2008. Modeling temporal variations in multipolarized radar scattering from intertidal coastal wetlands. Journal of Photogrammetry and Remote Sensing, vol. 63, no. 5, pp. 559-577.

SOLOVEY T., 2013. Zastosowanie metod teledetekcyjnych do identyfikacji obszarów podmokłych na Nizinach Środkowopolskich. Biuletyn Państwowego Instytutu Geologicznego, vol. 454, pp. 133-139.

ToWnsend P.A., WaLSH S.J., 1998. Modeling floodplain inundation using an integrated GIS with radar and optical remote sensing. Geomorphology, vol. 21, no. 3-4, pp. 295-312.

TUCKER C.J., 1979. Red and photographic infrared linear combinations for monitoring vegetation. Remote Sensing of Environment, vol. 8, no. 2, pp. 127-150.

Ulaby F.T., Long D.G., Blackwell W., Elachi C., Fung A., Ruf C., Sarabandi K., Zebker H., van ZYL J., 2014. Microwave Radar and Radiometric Remote Sensing. Michigan: University of Michigan Press.

Ulaby F.T., Moore R.K., Fung A.K., 1986. Microwave Remote Sensing: Active and Passive. Vol. III. From Theory to Applications. Remote Sensing Series, vol. 4, MA: Artech House.

Wang Y., Hess L.L., Filoso S., Melack J.M., 1995. Understanding the radar backscattering from flooded and nonflooded Amazonian forests: Results from canopy backscatter modeling. Remote Sensing of Environment, vol. 54, no. 3, pp. 324-332.

Wickel A.J., Jackson T.J., Wood E.F., 2001. Multitemporal monitoring of soil moisture with RADARSAT SAR during the 1997 Southern Great Plains hydrology experiment. International Journal of Remote Sensing, vol. 22, no. 8, pp. 1571-1583. 